\title{
PENGGUNAAN JUS KULIT BUAH NAGA UNTUK MENGATASI NYERI SAAT MENSTRUASI (DISMENOREA)
}

\section{DRAGON FRUIT SKIN FOR OVERCOME PAIN WHEN MENSTRUATION (DISMENOREA)}

\author{
Layla Imroatu Zulaikha ${ }^{(1)}$, Yulia Paramita ${ }^{(2)}$ \\ Prodi DIII Kebidanan Universitas Islam Madura
}

\begin{abstract}
Menstrual pain, or medical dysmenorrhea, is pain in the lower abdomen during menstruation and can also be felt on the hips, lower back, or thighs. The pain is convulsive (convulsions), which are felt by some women at the beginning of menstruation. Dysmenorrhoea can also be overcome non-pharmacologically, which can naturally reduce the intensity of the pain. This research is an experimental analytical research that is a research on the level of naturalness (setting) where research is in addition to survey research and naturalistic (qualitative). Essentially, experimental research is to examine the effect of the treatment on the behavior that results from the treatment.

This study was conducted to determine the intensity of menstrual pain after eating dragon fruit skin juice. The first 3 months focused on reducing the intensity of pain after eating dragon fruit skin juice with a composition of 100 grams of dragon fruit skin mixed with sugar and enough water. The second 3 months focused on reducing the intensity of pain after eating dragon fruit skin juice with a composition of 200 grams of dragon fruit skin mixed with sugar and sufficient water. The third 3 months focused on reducing the intensity of pain after eating dragon fruit skin juice with a composition of 100 grams of dragon fruit skin mixed with milk and sufficient water.

In addition, the study also received information on how to reduce the intensity of menstrual pain by applying non-pharmacological techniques by using dragon fruit
\end{abstract}

Keywords: Dysmenorrhea, dragon fruit skin

\begin{abstract}
ABSTRAK
Nyeri haid atau dalam istilah medis disebut dengan dismenorea merupakan rasa sakit di perut bagian bawah selama menstruasi dan juga dapat dirasakan di pinggul, punggung bawah, atau paha, rasa sakit bersifat spasmodik (kram), pada umumnya dirasakan sebagian wanita pada awal masa menstruasi. Dismenorea juga dapat diatasi secara nonfarmakologis yang mampu mengurangi intensitas nyeri secara alami. Penelitian ini merupakan penelitian analitik eksperimen yaitu suatu penelitian yang didasarkan pada tingkat kealamiahannya (setting) tempat penelitian selain penelitian survey dan naturalistik (kualitatif). Pada hakikatnya penelitian eksperimen adalah meneliti pengaruh perlakuan terhadap perilaku yang timbul sebagai akibat perlakuan.
\end{abstract}


Penelitian ini dilakukan untuk mengetahui intensitas nyeri mentruasi setelah mengkonsumsi jus kulit buah naga. 3 bulan pertama menitikberatkan pada penurunan intensitas nyeri setelah mengkonsumsi jus kulit buah naga dengan komposisi 100gr kulit buah naga dicampur dengan gula dan air secukupnya. 3 bulan kedua menitikberatkan pada penurunan intensitas nyeri setelah mengkonsumsi jus kulit buah naga dengan komposisi 200gr kulit buah naga dicampur dengan gula dan air secukupnya. 3 bulan ketiga menitikberatkan pada penurunan intensitas nyeri setelah mengkonsumsi jus kulit buah naga dengan komposisi 100gr kulit buah naga d campur dengan susu dan air secukupnya.

Selain itu penelitian juga memperoleh informasi tentang cara mengurangi intensitas nyeri menstruasi dengan menggunakan teknik nonfarmakologi yaitu dengan cara mengkonsumsi jus kulit buah naga.

Kata Kunci : Dismenorea, Kulit buah naga

\section{PENDAHULUAN}

Menstruasi merupakan perdarahan yang teratur dari uterus sebagai tanda bahwa organ kandungan telah berfungsi matang (Kusmiran, 2012). Nyeri haid (dismenorea) umumnya dirasakan sebagian wanita pada awal masa menstruasi. Pada beberapa wanita, rasa sakit di bagian bawah perut ini tidak begitu terasa hingga mereka tetap dapat beraktivitas seperti biasa. Namun sebagian lain merasakan nyeri yang tidak tertahankan hingga tidak mampu melakukan apapun. Nyeri haid biasanya dirasakan sesaat sebelum atau selama periode menstruasi, puncaknya setelah 24 jam, dan mereda setelah 2 sampai 3 hari. Nyeri haid atau dalam istilah medis disebut dengan dismenorea merupakan rasa sakit di perut bagian bawah selama menstruasi dan juga dapat dirasakan di pinggul, punggung bawah, atau paha, rasa sakit bersifat spasmodik (kram).

Terdapat 2 macam Dismenorea, yaitu dismenorea primer dan dismenorea sekunder. Dismenorea primer terjadi pada saat menstruasi biasa atau menstruasi normal. Sedangkan Disemenorea sekunder terjadi disebabkan oleh adanya gangguan tertentu pada alat reproduksi wanita seperti endometriosis atau fibroid. Penyebab Dismenorea primer belum diketahui secara jelas, rahim (uterus) pada wanita yang menglami dismenorea tetap normal. Adanya penumpukan bahan kimia dalam tubuh yang disebut prostaglandin di lapisan rahim. Dalam jumlah normal, Prostaglandin berfungsi membantu rahim berkontraksi dan mengeluarkan lapisan rahim selama periode. Pada wanita yang mengalami nyeri haid atau dismenorea tampaknya ada penumpukan prostaglandin dalam jumlah yang terlalu banyak, atau rahim mungkin ekstra sensitif terhadap prostaglandin. Hal ini dapat menyebabkan rahim berkontraksi lebih keras. Hal ini akan mengurangi suplai darah ke rahim dan menyebabkan rasa sakit. 
Hasil penelitian Pusat Informasi dan Konseling Kesehatan Reproduksi Remaja (PIK-KRR) di Indonesia tahun 2009 angka kejadian dismenorea primer $72,89 \%$ dan dismenorea sekunder 27,11\%. Angka kejadian dismenorea sekitar 45-95\% dikalangan wanita usia produktif (Proverawati Misaroh, 2009). Dismenorea dapat dikurangi secara farmakologis dan non farmakologis. Secara nonfarmakologis diantaranya istirahat yang cukup, relaksasi dalam atau yoga, melakukan aktivitas fisik seperti olah raga, bersepeda dan senam aerobik, akupresure, mandi dengan air hangat, kompres dengan kantong air panas (bulibuli) / hangat pada bagian yang terasa nyeri, serta mengonsumsi minuman herbal (Kozier \& Erb's, 2009 \& Bobak, 2005). Salah satu minuman herbal yang dapat mengurangi dismenorea adalah jus kulit buah naga. Kulit buah naga yang bersisik tersebut dipercaya mengandung zat pentacyclic, triyepene, dan taraxast yang dapat membuat lentur pembuluh darah anda, sehingga darah akan mengalir dengan lancar ke seluruh tubuh. Jika pembuluh darah anda lentur, maka pembuluh darah tak mudah pecah meskipun mendapatkan tekanan yang kuat dari jantung. Lenturnya pembuluh darah juga mampu mengurangi rasa nyeri di awal menstruasi.

\section{METODE PENELITIAN}

\section{Lokasi Penelitian}

Penelitian ini akan dilaksanakan di lingkungan Universitas Islam Madura, hal ini dikarenakan banyaknya mahasiswi yang mengalami nyeri menstruasi namun terbatas untuk punya kesadaran tinggi akan pentingnya pengetahuan tentang cara mengatasi nyeri saat menstruasi.

\section{Pelaksanaan Penelitian}

Pada penelitian ini menggunakan data primer dimana data diperoleh langsung dari lapangan yaitu dengan melakukan tes langsung kepada siswa yang mengalami dismenore primer menggunakan Visual Analogue Scala (VAS). Memberikan jus kulit buah naga pada siswa yang mengalami dismenorea kemudian mengkaji intensitas nyeri yang dialami setelah mengkonsumsi jus kulit buah naga. Setelah diberi jus kulit buah naga kemudian di test kembali nyeri yang dialami mahasiswi menggunakan VAS.

\section{Proses Pengolahan Data}

Adapun Proses Pengolahan data dalam penelitian ini adalah sebagai berikut:

a. Memberikan jus kulit buah naga kepada 100 responden dengan komposisi air, kulit buah naga dan gula.

b. Sebelum dan sesudah mengkonsumsi di test menggunakan skala VAS

c. Setelah itu data yang diberoleh diolah untuk mengidentifikasi perubahan. 
Metode Analisis Data

Analisis adalah suatu proses penyusunan data agar dapat ditafsirkan. Analisis yang digunakan terhadap data yang diperoleh dalam penelitian ini menggunakan analisis data secara induktif. Proses analisis data dimulai dengan menelaah seluruh data yang responden yang mengalami dismenorea dengan menggunakan Visual Analogue Scala (VAS). Setelah mengetahui intensitas nyeri kemudian diberikan treatment untuk mengkonsumsi jus kulit buah naga sesuai dengan tahapan komposisi yang telah ditentukan.

\section{PEMBAHASAN DAN HASIL}

\subsubsection{Intensitas Nyeri sebelum} mengkonsumsi jus kulit buah naga

Tabel 1 : Distribusi frekuensi berdasarkan intensitas nyeri responden di Prodi DIII Kebidanan Universitas Islam

\begin{tabular}{ccc}
\multicolumn{2}{c}{ Madura } & \\
\hline Intensitas Nyeri & Frekuensi & Persentase \% \\
\hline Nyeri Ringan & 25 & 25,0 \\
Nyeri sedang & 45 & 45,0 \\
Nyeri berat & 20 & 20,0 \\
Nyeri sangat berat & 10 & 10,0 \\
\hline Total & 100 & 100
\end{tabular}

Berdasarkan tabel 1 diatas dapat diketahui bahwa dari 100 responden 25 responden (25\%) mengalami nyeri ringan, 45 (45\%) responden nyeri sedang, 20 (20\%) responden merasa nyeri berat dan $10(10 \%)$ nyeri sangat berat.
3.1.2 Intensitas Nyeri dismenorea setelah mengkonsumsi jus kulit buah naga.

Tabel 2 : Distribusi frekuensi responden berdasarkan intensitas nyeri di Prodi DIII Kebidanan Universitas Islam Madura

\begin{tabular}{ccc}
\hline Intensitas Nyeri & Frekuensi & Persentase \% \\
\hline Tidak Nyeri & 10 & 10,0 \\
Nyeri Ringan & 30 & 30,0 \\
Nyeri sedang & 40 & 40,0 \\
Nyeri berat & 15 & 15,0 \\
Nyeri sangat berat & 5 & 5,0 \\
\hline Total & 100 & 100
\end{tabular}

Berdasarkan tabel 6 diatas dapat diketahui bahwa dari 100 responden 10 responden $(10,00 \%)$ merasa tidak nyeri saat menstruasi, 30 responden $(30 \%)$ mengalami nyeri ringan, 40 (23\%) responden nyeri sedang, $15(15 \%)$ responden merasa nyeri berat dan $5(5 \%)$ nyeri sangat berat.

Terdapat perubahan yang sangat signifikan tentang intensitas nyeri setelah mengkonsumsi jus kulit buah naga. Kondisi ini dibuktikan dengan adanya penurunan jumlah mahasiswa yang mengalami dismenorea yaitu dari 20 responden (20\%) yang mengalami nyeri berat menjadi 15 (15\%) responden nyeri berat. Bukti yang kedua adalah berkurangnya jumlah mahasiswa yang sebelumnya mengalami dismenorea menjadi tidak mengalami dismenorea sebanyak 10 (10\%) responden.

Data intensitas nyeri yang dialami pasien sebelum dan sesudah mengkonsumsi jus buah naga mengalami perubahan yang cukup significant. Banyak mahasiswi yang 
merespon bahwa keluhan nyeri menstruasi berkurang bahkan ada yang tidak merasakan nyeri. Sedangkan berdasarkan uji statistik t test menunjukan angka signifikasi 0,000 dengan probability 0,05 . Artinya bahwa jika nilai probability dibawah derajat kemaknaan $(0,000-0,05)$ maka Ho ditolak dan H1 diterima, dengan demikian mahasiswi yang mengkonsumsi jus kulit buah naga mengalami penurunan nyeri menstruasi.

\section{PENUTUP}

Hasil eksperimen setelah mahasiswi yang mengalami dismenorea mengkonsumsi jus kulit buah naga diperoleh data bahwa ada penurunan nyeri menstruasi yang dialami mahasiswi. Kulit buah naga yang bersisik tersebut dipercaya mengandung zat pentacyclic, triyepene, dan taraxast yang dapat membuat lentur pembuluh darah anda, sehingga darah akan mengalir dengan lancar ke seluruh tubuh. Jika pembuluh darah anda lentur, maka pembuluh darah tak mudah pecah meskipun mendapatkan tekanan yang kuat dari jantung. Lenturnya pembuluh darah juga mampu mengurangi rasa nyeri di awal menstruasi.

\section{DAFTAR PUSTAKA}

Arikunto, Suharsimi. 2006. Prosedur Penelitian (Suatu Pendekatan Praktik. Jakarta : PT RINEKA CIPTA.
Friskila, Linda, 2013. Ekstraksi Zat Warna Alami Dari Kulit Buah Naga (Hylocereus polyhizus) Untuk Pembuatan Agar-agar. diunduh 20 Mei 2017.

Glasier, Anna. 2005. Keluarga Berencana dan Kesehatan Reproduksi. Jakarta : EGC

Hidayat, Aziz Alimul. 2009. Metode Penelitian \& Teknik Analisis Data. Jakarta : Salemba Medika.

Kartono, Kartini. 2006. Psikologi Wanita 1 (Mengenal Gadis Remaja \& Wanita dewasa). Bandung : Mandar Maju

Lleweyn, Derek, Jones. 2009. Setiap Wanita. Jakarta : Delapratasa Publishing

Manuaba, Chandranita. dkk. 2008. GawatDarurat Obstetri-Ginekologi \& ObstetriGinekologi Sosial untuk Profesi Bidan. Jakarta : ECG

Maryanti, Dwi \& Mjestika Septikasari. 2009. Kesehatan Reproduksi (Teori dan Praktikum). Yogjakarta : Nuha Medika

Maulana, Mirza. 2009. Seluk Beluk Reproduksi dan Kehamilan. Yogyakarta : Garailmu 
Noor, Ilham. Dkk. 2016. Identifikasi Kandungan Ekstrak Kulit Buah Naga Merah Menggunakan Fourier Transform Infrared (FTIR) dan Fitokimia. Aceh. Journal of Aceh Physics Society Vol. 5 No. 1 pp. 14-16 2016

Notoatmodjo, Soekidjo. 2007. Kesehatan Masyarakat(Ilmu \& Seni). Jakarta : PT Rineka Cipta

Pinem, Saroha. 2009. Kesehatan Reproduksi \& Kontrasepsi. Jakarta : Trans Info Medika (TIM).

Prawirohadjo, Sarwono. 2005. Ilmu Kebidanan. Jakarta : Yayasan Bina Pustaka.

Sitiatava, R.P, Buah Naga ; Tidak Cuma Enak, tetapi juga Sarat Obat-obatan Cespleng ( Jogjakarta : Laksana, 2011 )

Saryono \& Sejati Waluyo. 2009. Sindrom Premenstruasi. Yogyakarta : Nuha Medika

Wahyuni, R. 2011. Pemanfaatan Kulit Buah Naga Super Merah. Pasuruan. Jurnal Teknologi Pangan Vol. 2 No. 1 